http://jurnaltarbiyah.uinsu.ac.id/index.php/raudhah

e-mail: jurnalraudhah@uinsu.ac.id

p-ISSN: 2338-2163

e-ISSN: $2716-2435$

\title{
Implimentasi Pendekatan Metode Kisah Qur'an Nilai Religiusdan Moral Di Ra Ar-Raudhah Anak Usia Dini Kota Sibolga Sumatera Utara
}

\author{
${ }^{1}$ Nurhikmah Pohan \\ UIN Sunan Kalijaga Yogyakarta \\ email: nurhikmah.pohan27@gmail.com \\ ${ }^{2} \mathrm{Hj}$.Marhumah \\ UIN Sunan Kalijaga Yogyakarta
}

Article received : 16 Agustus 2021

Article accepted : 15 Oktober 2021
Review process : 10 September 2021

Article published : 01 Desember 2021

\begin{abstract}
Abstrak
Implimentasi Pendekatan Metode Kisah Qurean Untuk Penanaman Moral Regilius Metode Kisah Qurean memberikan dampak terhadap Pemahaman Moral, Nilai dan Religius. Penelitian ini mengkaji beberapa fokus pada Bagaimana Implementasi dan Karakteristik Pendekatan Metode Kisah Qur"ean Nilai Religius dan Moral di RA ArRaudhah Sibolga Sumatera Utara. Jenis penelitian ini adalah penelitian kualitatif dengan pendekatan psikologi perkembangan. Metode pengumpulan data menggunakan observasi, wawancara, dokumentasi. Teknik analisis data yang digunakan adalah Reduksi data (data reduction), Penyajian data (data display), dan Penarikan kesimpulan dan verifikasi (conclution drawing and verification). Teori yang digunakan oleh peneliti yaitu teori dari Vygotsky dalam Kisah Qur'an pemahaman kognitif anak berkembang dengan apa yang telah di kisahkan terhadap sifat dan perilaku para Nabi karena berkaitan dengan pikiran sadar seorang anak. Semakin bertambahnya besarnya koordinasi dan pengendalian dunia kognitif anak berkembang pesat, semaki kreatif, bebas imajinatif. Hasil dari penelitian ini adalah Implimentasi yang telah dilakukan oleh guru RA ARRaudhah Sibolga Sumatera Utara terhadap nilai moral regilius telah membangkitkan pemahaman terhadap peserta didik, melalui metode kisah Qur ${ }^{\text {ee }}$ an, anak dapat memahami sifat-sifat yang di anjurkan oleh allah SWT melalui sifat dan perilakukan yang di lakukan oleh para NabiNabi, serta guru telah melakukan penerapan metode kisah qur"ean untuk mengajarkan nilai dan moral religius untuk anak usia dini sehingga menumbuhkan suatu sifat peserta didik yang sopan dan patuh kepada orang tuanya serta gurunya melakukan perbuatan baik dan meninggalkan yang dilarangya dan karakteristik metode kisah Quream di RA AR-Raudhah Sibolga Sumatera Utara telah menumbuhkan rasa percaya diri, menghargai sesamanya serta anak paham serta mandiri dalam melakukan semua hal, membuat anak saling berbagi dan menolong sesamnya, metode yang sesuai membuat anak lebih disiplin dalam setiap permainan dan cerita yang sesuai dengan aturan yang ditetapkan dan anak mampu mengendalikan tutur bahasanya terhadap temanteman sebaya maupun guru
\end{abstract}

Kata kunci: Metode kisah Qur'an, nilai dan moral religius, anak usia dini

\section{Abstract}

The Implementation of the Qur'anic Story Method Approach for Religious Moral Cultivation The Qur'anic Story Method has an impact on Moral, Value and Religious Understanding. This study examines several focuses on how the implementation and characteristics of the Qur'an Story Method approach, religious and moral values, at RA ArRaudhah Sibolga, North Sumatra. This type of research is a qualitative research with a developmental psychology approach. Methods of data collection using observation, interviews, 
http://jurnaltarbiyah.uinsu.ac.id/index.php/raudhah

e-mail: jurnalraudhah@uinsu.ac.id

p-ISSN: 2338-2163

e-ISSN: $2716-2435$

documentation. The data analysis technique used is data reduction, data display, and conclusion drawing and verification. The theory used by the researcher is the theory of Vygotsky in the story of the Qur'an, children's cognitive understanding develops with what has been told of the nature and behavior of the Prophets because it is related to the conscious mind of a child. The greater the amount of coordination and control in the cognitive world, children develop rapidly, become more creative, free to imaginatively. The result of this research is that the implementation of the teacher RA ARRaudhah Sibolga, North Sumatra, on religious moral values has awakened understanding of students, through the Qur'anic story method, children can understand the traits recommended by Allah SWT through their character and behavior. what the Prophets, as well as teachers have done, have implemented the quran story method to teach religious values and morals for early childhood so as to foster a character of students who are polite and obedient to their parents and the teacher does good deeds and leaves the bad. the prohibition and characteristics of the Qur'am story method in RA ARRaudhah Sibolga, North Sumatra, have fostered self-confidence, respect for each other and children understand and are independent in doing all things, make children share and help each other, appropriate methods make children more disciplined in each game and story according to the set rules Applies and children are able to control their speech towards peers and teachers

Keywords: Qur'an story method, religious values and morals, early childhood

\section{A. PENDAhuluan}

Pendekatan Metode Kisah Qur'an mendorong siswa agar memiliki jiwa investigatif, memiliki jiwa rasa ingin tahu yang tinggi, dan mampu mengembangkan dan membangun konsep sendiri berdasarkan pengalaman pembelajarannya. Maka dari itu, pembelajaran tersebut hendaknya mampu menarik perhatian dan rasa ingin tahu peserta didik. Pembelajaran saintifik tidak hanya memandang hasil akhir dari proses pembelajaran, akan tetapi lebih menekankan pada proses kegiatannya.(Syaeful Rokim, 2015)

Pendekatan dalam proses pembelajaran yang tepat dan sesuai pada anak akan menentukan keberhasilan untuk mencapai perkembangan secara optimal sesuai dengan potensi anak tersebut. Dengan perkembangan secara optimal, anak akan memiliki kompetensi sikap, pengetahuan, dan keterampilan dalam memasuki jenjang selanjutnya. Oleh karena itu sangat penting bagi seorang guru dalam menguasai pendekatan yang akan digunakan dalam proses pembelajaran.( Rohinah, 2018) Implementasi pendekatan Metode kisah Qurean dalam proses pembelajaran harus disiapkan secara matang, seperti dana yang dibutuhkan, sarana dan prasarana dan lain sebagainya. Dari hasil observasi yang sudah dilakukan oleh Peneliti Raudhah Kota Sibolga Sumatera Utara, bahwa di lembaga pendidikan anak usia dini, khususnya TK sudah menggunakan pendekatan Metode Kisah Qur"an. Meskipun dalam praktiknya masih belum terlaksana dengan baik, sesuai dengan peraturan yang sudah ditetapkan oleh pemerintah. Seperti yang sudah tertera dalam PERMENDIKBUD 146 Tahun 2014 tentang Kurikulum PAUD 2013. 
http://jurnaltarbiyah.uinsu.ac.id/index.php/raudhah

e-mail: jurnalraudhah@uinsu.ac.id

p-ISSN: 2338-2163

e-ISSN: $2716-2435$

Sekolah dan para pendidik tidak hanya mengajarkan anak dengan kegiatan seperti mengaji, menghafal doa-doa dan mengajarkan praktek ibadah tetapi dalam mengembangkan karakter religiusitas pada anak usia dini guru memiliki program khusus yang telah diterapkan disekolah. Sekolah menggunakan metode kisah-kisah yang ada dalam al-qur"ean untuk mengembangkan karakter religius anak, bahkan sekolah memberikan pelatihan khusus kepada guru secara bergiliran tentang bagaimana cara bercerita dengan baik dan benar kepada anak. Penyampaian kisahkisah ini dilakukan di area ibadah secara bervariasi, pemilihan kisah disesuaikan dengan nilai-nilai ibadah yang ingin ditanamkan dalam diri anak, dalam penyampaian kisah guru menggunakan berbagai macam media seperti boneka tangan, gambar tiga dimensi yang berlatar belakang islam, buku kisah yang memiliki gambar dan berwarna.

Pemilihan kisah lebih banyak menceritakan mengenai tokoh-tokoh yang disebutkan dalam Al-Qur"an serta fenomena-fenomena yang dikisahkan dalam AlQur"ean, kisah-kisah ini dapat dijadikan teladan dikarenakan kisah dalam Al- Qur"an sarat akan pesan religi, pesan ini diharapkan dapat diserap oleh anak dari sejak dini, sehingga tumbuh dan tertanam di dalam diri anak karakter religius. Karakter yang tertanan dalam diri anak didapatkan dari nilai-nilai karakter yang ditananamkan pada diri anak melalui penghayatan terhadap makna dan maksud dari cerita atau kisah yang di dengar (meaning and intention of story).

Al-qur"an memiki banyak kisah-kisah, meskipun bukan dongeng. Kisah- kisah teladan tersebut kalau diceritakan guru kepada anak-anak dengan bahasa yang mudah dan sederhana akan selalu disukai anak-anak. Pada usia dini, perhatian anak lebih tertuju pada cara guru menceritakan agama dari pada isi ajarannya dan cerita akan lebih menarik jika berhubungan dengan masa anakanak karena sesuai dengan jiwa kekanak-kanakannya. Dengan caranya sendiri anak mengungkapkan pandangan teologisnya, pernyataan dan ungkapannya tentang Tuhan lebih bernada individual, emosional, dan spontan tapi penuh arti teologis. Pengembangan karakter religiusitas pada anak-anak taman kanak- kanak harus menggunakan metode-metode yang kreatif dan menyenangkan agar tujuan proses pembelajaran tercapai dengan baik.( Masganti Sit, 2016)

Implimentasi Pendekatan Metode Kisah Qur'an Nilai Religiusdan Moral Di Ra Ar-Raudhah Anak Usia Dini Kota Sibolga Sumatera Utara 
http://jurnaltarbiyah.uinsu.ac.id/index.php/raudhah

e-mail: jurnalraudhah@uinsu.ac.id

p-ISSN: 2338-2163

e-ISSN: 2716-2435

\section{B. METODE PENELITIAN}

Penelitian yang dilakukan ini termasuk dalam penelitian lapangan di RA AR-Raudhah Sibolga Sumatera Utara, dengan pendekatan kualitatif. Subjek penelitian yang menjadi sumber data dalam penelitian ini adalah: Kepala Sekolah RA Ar-Raudhah Sibolga Sumatera Utara sebagai pengelolah, penentu kebijakan dan sebagai narasumber terkait gambaran umum di mulai dari awal berdiri hingga saat ini. Memberikan informasi terkait guru-guru yang mengajar di RA Ar-Raudhah Sibolga Sumatera Utara Sekertaris kepala sekolah RA Ar-Raudhah Sibolga Sumatera Utara, guna memperoleh data berupa dokumen sekolah seperti, profil sekolah, kurikulum, administrasi, dan program tahunan sekolah.Guru-guru yang mengajar di RA Ar-Raudhah Sibolga Sumatera Utara yang terlibat langsung (berinteraksi) dalam menanamkan nilai pada anak. Sumber data dalam penelitian ini difokuskan pada dua bagian yaitu; data primer (sumber pertama) dan data sekunder (sumber data yang tidak langsung).Peneliti mengambil ke-dua data tersebut karena dalam penelitian ini, peneliti sangat membutuhkan informasi dari semua Subjek untuk dapat menjawab Rumusan Masalah. Teknik Pengumpulan Data menggunakan observasi, wawancara dan dokumentasi. Analisis data dengan Pengumpulan data, Reduksi data, Penyajian data .

\section{HASIL TEMUAN DAN PEMBAHASAN}

\section{Metode Kisah Qur'an Nilai dan Moral Religius Anak Usia Dini}

Prinsipnya pembelajaran yang dilaksanakan di RA AR-Raudhah Sibolga Sumatera Utara berlatar belakang nilai-nilai Islami, RA AR-Raudhah Sibolga Sumatera Utara menggunakan model pembelajaran area, dimana di setiap area akan memiliki tujuan perkembangan yang berbeda pula. RA ini juga menggunakan pembelajaran berbasis islami dan kontekstual. Pembelajaran kontekstual dapat dilihat dari penanaman nilai-nilai kearifan lokal yang dilaksanakan oleh RA tersebut, diantaranya seperti memberikan pengetahuan kepada anak mengenai bahasa daerah (bahasa batak), membiasakan anak untuk berbicara bahasa batak pada hari- hari tertentu.( Saiful Cahya,, 2016)

Pembelajaran berbasis Seperti kita ketahui bahwa anak-anak usia dini memiliki rasa ingin tahu yang sangat besar (strong desire to investigate things) dan memorinya terus bertambah. Sebagaimana yang telah dijelaskan pada bab-bab sebelumya bahwa anak usia dini sangat haus akan pengetahuan baru, anak seolaholah mampu menyerap segala hal dalam waktu cepat, maka dari itu hal ini harus dapat dimanfaatkan sebaik mungkin oleh pendidik untuk mengenalkan hal-hal baru kepada anak sesuai dengan tingkatan usia anak.

Implimentasi Pendekatan Metode Kisah Qur'an Nilai Religiusdan Moral Di Ra Ar-Raudhah Anak Usia Dini 
http://jurnaltarbiyah.uinsu.ac.id/index.php/raudhah

e-mail: jurnalraudhah@uinsu.ac.id

p-ISSN: 2338-2163

e-ISSN: $2716-2435$

Contoh kegiatan rutin yang diberikan oleh guru dalam mengembangkan karakter religiusitas pada anak di sekolah adalah membiasakan anak mengucapkan dan menjawab salam, membiasakan anak berdoa sebelum dan sesudah melakukan kegiatan, mengajarkan anak membaca dan menghafal ayat-ayat Al-Qur"an, mengajarkan anak kegiatan-kegiatan beribadah (sholat dhuha berjamaah), membiasakan anak mengucapkan maaf dan terimakasih, membacakan kisah-kisah yang ada dalam Al-Qur"ean yang sangat cepat seperti terlihat dalam perkembangan pengertian dan keterampilan berbicara. Montessori masa ini anak telah dapat menerima dan memahami perintah dengan cukup baik Perkembangan bahasa yang sangat pesat ini dapat dimanfaatkan oleh pendidik untuk membentuk karakter anak melalui berbagai macam kegiatan yang membutuhkan perkembahasa anak.

Perkembangan bahasa anak pada masa ini dapat dilihat dari kegiatan sehariharinya seperti: (a), menyapa dengan sapaan yang sopan lagi santun (anak-anak menggunakan bahasa batak misalnya, karimo kasih, mulak julo auda, dll), telah mampu membaca dan bahkan menghafal ayat-ayat pendek Al-Qur"an, mampu memahami cerita yang disampaikan oleh guru, mampu memahami kalimat perintah, anak mampu memahami penulisan huruf dan angka arab Selanjutnya, setiap guru yang ingin melaksanakan proses pembelajaran diwajibkan untuk membuat perencanaan pembelajaran terlebih dahulu sehingga pembelajaran yang akan dilaksanakan sejalan dengan tujuan yang ingin dicapai. Perencanaan pembelajaran meliputi perencanaan tahunan, perencanaan semester (RPS), perencanaan mingguan (RPPM) dan perencanaan harian (RPPH). Penuturan dari kepala sekolah RA ARRaudhah Sibolga Sumatera Utara bahwa setiap guru wajib membuat perencanaan pembelajaran sebelum proses pembelajaran dilaksanakan. Hasil dari wawancara dengan Guru kelas B1 RA AR-Raudhah Sibolga Sumatera Utara menjelaskan bahwa kisah-kisah yang dibawakan untuk anak-anak diambil dari buku cerita kisah-kisah yang terdapat di dalam Al-Quran, baik buku itu menceritakan tentang para nabi, sahabat, toko-tokoh lain yang namanya disebutkan dalam Alqur"an, binatang dan tumbuhan, serta sejarah yang sarat akan kandungan nilai-nilai di dalamnya. Salah satu cerita yang disampaikan oleh guru adalah cerita Nabi Musa yang mana kisah ini sarat akan nilai-nilai kehidupan yang dapat ditanamkan dalam diri anak sejak dini.

Betapa nabi musa dari kecil terlahir ditengah kedzaliman Fir"eaun tetapi dengan kuasa Allah Nabi Musa dibesarkan sendiri oleh Fir"eaun Bahasa yang digunakan oleh para guru dalam menyampaikan kisah-kisah begitu sederhana, ini dimaksudkan agar anak mampu menyaring informasi dengan baik dan anak dapat memperoleh pemahaman terhadap kisah yang 
http://jurnaltarbiyah.uinsu.ac.id/index.php/raudhah

e-mail: jurnalraudhah@uinsu.ac.id

p-ISSN: 2338-2163

e-ISSN: $2716-2435$

diceritakan guru. Dari hasil observasi terlihat bahwa guru mampu membuat anak- anak terbuai dengan cerita kisah yang sedang mereka dengarkan, anak-anak menunjukkan ekspresi kagum, senang, tertawa, dan antusias setiap kata-kata yang keluar dari mulut gurunya. Guru menirukan suara tokoh-tokoh yang berperan dalam kisah tersebut, seperti yang dilakukan oleh guru kelas B1 ketika menirukan suara yang berat untuk satu tokoh dan suara yang lebih ringan untuk tokoh yang lain, ini dapat menarik perhatian anak sekaligus membuat anak lebih memahami dialog dalam kisah tersebut

Selama kegiatan berkisah berlangsung terlihat jelas anak-anak terpesona dengan kisah yang disampaikan oleh wali kelas anak BI dengan penuh penghayatan. Anak-anak seperti terhipnotis dengan kisah yang mereka dengar sehingga emosi dari anak-anak juga ikut terbawa dalam alur kisah yang sedang dibawakan oleh guru. Ketika kegiatan sedang berlangsung, suasana dalam kisah Nabi Musa As menggambarkan bahwa begitu menegangkannya ketika Nabi Musa harus melawan tentara Fir"eaun yang mempunyai kekuatan sihir, dan harus menyebrerangi lautan, begitu pula saat menggambarkan emosi yang berbeda anak terlihat bisa merasakan emosi tersebut, ketika Nabi Musa diselamatkan oleh Allah dan disusui oleh ibu kandungnya, anak-anak dapat merasakan emosi bahagia di bagian cerita ini. Ketika guru menceritakan kisah ini, guru menggunakan media boneka tangan sehingga anak lebih semangat memerhatikan setiap gerakan guru da mendengarkan guru, anak terlihat sangat senang mendengarkan cerita yang dibawakan oleh wali kelas BI.

Metode kisah Qur"eani yang digunakan di RA AR-Raudhah Silboga Sumatera Utara selalu mengaitkan setiap materi yang akan disajikan dengan nilai-nilai pendidikan islam, sehingga perkembangan nilai agama dan moral anak dapat terstimulasi. Hal ini dapat dilihat ketika kegiatan berkisah sedang berlangsung, guru tidak lupa memasukkan hadits-hadits dan ayat Al-Qur-an yang berkaitan dengan kisah, ini dilakukan untuk menguatkan aqidah dan akhlak anak melalui isi kisah. Dari pemaparan di atas, dapat disimpulkan ada beberapa hal dan tahapan yang harus dipersiapkan oleh guru dalam berkisah, ini dilakukan supaya mempermudah dalam mengembangkan karakter religius pada anak, antara lain:

1. Materi kisah, yaitu berupa persiapan awal, saat materi kisah sudah dipilih, ada beberapa hal penting yang harus dilakukan, yaitu mengkaji isi dan misi dari kisah, menentukan alur berkisah, dan merancang bagaimana membuka dan menutup kegiatan berkisah.

2. Mengkaji kisah, sebelum kisah diceritakan pada anak-anak, ada baiknya guru benar-benar memahami isi kisah tersebut, dengan demikian guru akan memahami nilai-nilai yang akan 
http://jurnaltarbiyah.uinsu.ac.id/index.php/raudhah

e-mail: jurnalraudhah@uinsu.ac.id

p-ISSN: 2338-2163

e-ISSN: $2716-2435$

ditekankan dalam cerita, mengetahui aspek apa saja yang perlu diperhatikan. Menetapkan tujuan yang spesifik sesuai dengan usia anak yang menjadi pendengar kisah, mengenali karakter tokoh yang ada dalam kisah, memperhitungkan waktu dan memperhatikan kondisi lokasi berkisah, memilih kata dan kalimat yang sesuai dan mudah dipahami anak, menentukan alat bantu ketika berkisah yang sesuai dan menarik.

3. Membuat alur cerita, walaupun kisah sudah ada di dalam buku bacaan, tetapi guru harus membuat ringkasan urutan kisah untuk mempermudah ketika kegiatan berlangsung.

4. Guru terlebih dahulu membuat rancangan untuk pembuka dan penutup kisah, yaitu membuka kisah dengan hal baru agar anak tidak bosan, hal ini menuntuk kreativitas seorang guru, dengan tujuan untuk menarik perhatian anak, misalnya dengan kegiatan bernyanyi terlebih dahulu, menirukan suara binatang yang terdapat dalam kisah, dramatisasi, dengan memainkan berbagai jenis tepuk tangan dan diakhiri dengan tepuk "diam" agar anak-anak memperhatikan. Selain pebuka, guru juga harus merancang penutupan cerita dengan menarik, dan menyelipkan pesan yang dapat mengembangkan nilai-nilai karakter religius anak.

5. Skill dalam berkisah, yaitu seorang pengisah harus memiliki keterampilan dalam menyampaikan kisah tersebut, ini diperlukan supaya anak mudah dalam memahami. Keterampilan yang dimaksud disini adalah: olah suara, olah tubuh, mimik wajah, dan bagaimana cara mengambil perhatian anak. Di RA AR-Raudhah Silboga Sumatera Utara, sebelum berkisah, guru terlebih dahulu membuat sebuah perjanjian dengan anak agar anak tetapi tenang ketika kegiatan berlangsung. Jika suasana sudah tidak kondusif guru akan berhenti berkisah. Dengan aturan yang dibuat demikian, anak-anak akan tetap tenang mendengarkan kisah yang sedang diceritakan guru.

6. Media yang digunakan, menggunakan alat peraga sangat efektif pada metode kisah Qur'eani, bukan hanya untuk menarik perhatian anak tetapi juga untuk membuat anak mudah dalam mengingat dan memahami, dan mengimplikasikannya dalam kehidupan ehari-hari nilai-nilai yang terkandung dalam kisah.

7. Memilih dan mempersiapkan lokasi untuk berkisah, hal ini tidak harus selalu dilakukan di dalam kelas, terkadang guru melakukannya di Aula, berkisah juga dapat dilakukan di luar ruangan tetapi guru harus memperhatikan keamanan, kenyamanan, kebersihan lokasi tersebut. Tempat yang digunakan untuk berkisah harus ditata dengan baik agar anak dapat melihat gurunya dengan baik. Seperti yang dilakukan oleh guru di RA AR-Raudhah Silboga 
http://jurnaltarbiyah.uinsu.ac.id/index.php/raudhah

e-mail: jurnalraudhah@uinsu.ac.id

p-ISSN: 2338-2163

e-ISSN: $2716-2435$

Sumatera Utara, sebelum kegiatan berkisah dilangsungkan, guru terlebih dahulu menata tempat duduk anak, seperti duduk melingkar.

8. Berkisah dengan menggunakan bantuan alat peraga, yakni kegiatan berkisah dengan menggunakan berbagai alat bantu. alat peraga yang digunakan guru antara lain boneka tangan, papan planel, big book, serta video. Sangat penting bagi guru untuk menguasai alat peraga sebelum memilih untuk menggunakannya, dikarenakan setiap alat peraga memiliki teknik tersendiri dalam penggunaannya untuk mendapatkan hasil maksimal.

9. Berkisah tanpa menggunakan media, yaitu berkisah tanpa menggunakan alat bantu, biasanya teknik ini akan membutuhkan kualitas suara, mimik wajah, serta gerak tubuh yang menggambarkan suasana dalam kisah yang sedang diceritakan. Mengekspresikan karakter dari tokoh yang dikisahkan, guru dapat mengekspresikannya dengan berbagai macam cara, antara lain dengan ekspresi visual (raut wajah, gerakan mata, gerak tubuh, gerak tangan) dan melalui intonasi suara. Ciri-ciri dari tokoh antara lain sifat tokoh, perasaan dan emosi dari tokoh. Guru tidak dapat mengekspresikan seluruh karakter tokoh melalui ekspresi visual saja, perlu intonasi suara yang disesuaikan dengan alur kisah. Paling tidak guru dapat mengembangkan dari tiga ekspresi dasar yang ada yakni sedih, gembira, dan marah.

10.Membuat bunyi dari suara, bunyi dalam sebuah kisah memiliki nilai esensial yang tidak memiliki makna secara linguistik. Melalui bunyi yang dikeluarkan oleh seorang pembaca maka akan mebuah isi dari kisah tersebut dapat dirasakan oleh orang yang mendengarkannya, kisah akan terasa lebih dramatis dan menarik. Oleh karena itu, untuk menguasai hal ini guru harus mengenali terlebih dahulu ciri-ciri prosodi, yakni tekanan kata dan kalimat, pola, intonasi, melodi dan waktu.

11.Menghidupkan suasana, sebuah kisah akan terasa menyenangkan untuk didengar jika pengisah dapat mebawa alur kisah dengan baik dan berurut, maka dibutuhlah skill khusus bagi guru dalam melakukan hal ini. Teknik yang harus dipelajari guru bagaimana mengoptimalkan klimaks kisah, membangkitkan humor di selasela kegiatan berkisah, mengikut sertakan anak dalam kisah ini seperti memberi pertanyaan atau menjawab pertanyaan anak, melakukan improvisasi dan interpola dengan menyiapkan unsur-unsur lingual yang dapat berwujud kata atau kalimat, memanfaatkan media yang tersedia di sekolah secara optimal, mengolah suara, ekspresi, serta pantomimik sehingga memunculkan minat anak untuk mendengarkan kisah tersebut dengan semangat. 
http://jurnaltarbiyah.uinsu.ac.id/index.php/raudhah

e-mail: jurnalraudhah@uinsu.ac.id

p-ISSN: 2338-2163

e-ISSN: 2716-2435

12.Memilih diksi dan struktur cerita, yaitu penggunaan kalimat di dalam kisah harus disesuaikan dengan kapasitas anak, yang dimaksud adalah kaalimat yang panjang dalah kisah harus dipersingkat oleh guru dengan kalimat yang lebih mudah dimengerti anak, katakata yang kurang tepat bagi perkembangan anak harus dihilangkan, dan kalimat yang sarat akan nilai-nilai pembelajaran lebih sering diulang penggunaannya ketika kegiatan sedang berlangsung, dengan seperti ini diharapkan anak akan lebih memahami maksud dari kisah tersebut

Pentingnya menanamkan pendidikan karakter kepada peserta didik atau generasi muda agar bisa mengontrol moral serta akhlak mereka, sehingga bisa melaksanakan seperti yang di ungkapkan oleh sang proklamator yaitu berdiri diatas kaki sendiri, dalam artian berkarakter atau mempunyai karakter Akhlak merupakan jiwa agama Islam sehingga diperlukan metode yang tepat dalam membentuk dan membinanya. Al-Qur"an memberikan isyarat bahwa kisah mempunyai peranan penting dalam membentuk dan membina akhlak Metode bercerita atau kisah dapat mengubah etika anak-anak karena sebuah kisah mampu menarik anak-anak untuk menyukai dan memperhatikan, serta merekam peristiwa dan imajinasi yang ada dalam kisah. Maksud cerita adalah baik (positif), namun disampaikan dengan redaksi negatif. Akibatnya, anak-anak lebih menangkap pesan mental emosional yang sifatnya negatif dari pesan sadar- rasional yang sifatnya positif, begitu pula mengajarkan anak dengan paksaan dapat menghambat perkembangan akademik anak Metode kisah Qureani yang digunakan di RA AR-Raudhah Silboga Sumatera Utara selalu mengaitkan setiap materi yang akan disajikan dengan nilai-nilai pendidikan Islam, sehingga perkembangan nilai agama dan moral anak dapat terstimulasi. Hal ini dapat dilihat ketika kegiatan berkisah sedang berlangsung, guru tidak lupa memasukkan hadis-hadis dan ayat Al-Qur-an yang berkaitan dengan kisah, ini dilakukan untuk menguatkan aqidah dan akhlak anak melalui isi kisah.

\section{SIMPULAN DAN SARAN}

Berdasarkan Hasil penelitian ini maka penulis dapat mengambil kesimpulan sebagai berikut:

1. Metode Kisah Qur"an, Nilai Religius, dan Moral, lainnya saling berhubungan satu dengan yang lainnya. Selain itu, melalui aktivitas dalam melakukan pembelajaran dengan metode 
http://jurnaltarbiyah.uinsu.ac.id/index.php/raudhah

e-mail: jurnalraudhah@uinsu.ac.id

p-ISSN: 2338-2163

e-ISSN: 2716-2435

Kisah Qurean juga diharapkan anak dapat mengekpresikan gagasan atau atau ide yang kreatifnya. Hal ini karena dalam berbagai aktivitas bidang berkisah tentang para nabi-nabi yaitu kekasih allah, terdapat banyak kesempatan bagi anak untuk mengembangkan kemampuan kreativitasnya. Hal ini terlihat ketika anak melakukan praktikan ketika proses belajar dilakukan. Dalam hal tersebut, disamping itu anak-anak menikmati kesempatan untuk memperagakan dengan yang telah diarahkan oleh guru, dan dilain sisi juga sekaligus mengepresikan kemampuan kreatifnya dalam melakukan sebuah contoh perilaku para nabi yang diceritakan oleh guru.

2. Perubahan pemahaman anak dalam hal ini lebih difokuskan pada penanaman nilai dan moral. Kisah Qurean menjadi bagian dari pembelajaran yang ada di RA AR-Raudhah Sibolga Sumatera Utara dalam rangka memenuhi kebutuhan dan penanaman nilai pada anak. Kisah Qurean mempunyai peran yang penting dalam proses perubahan tersebut. Seperti hasil observasi penulis dan wawancara mendalam yang penulis lakukan kebeberapa pihak yang relevan, seperti kepala sekolah, tenaga pendidikan, guru Kelas anak-anak orangtua murid, dijelaskan bahwa ada korelasi yang positif antara keikutsertaan anak-anak dengan perubahan perilaku dalam keseharian. Berdasarkan hal tersebut, proses perubahan perilaku anak usia dini di RA AR-Raudhah Sibolga Sumatera Utara melalui salah satunya Metode Kisah Qur ${ }^{\text {ee }}$ adalah:mempunyai rasa percaya diri, menumbuhkan sifat pemberani, menumbuhkan rasa mandiri, menumbuhkan rasa ingin berbagi, menolong dan membantu teman, jadi anak yang kreatif, mentaati aturan atau disiplin, dan mampu mengendalikan emosi.

Adapun Beberapa temuan sekaligus saran yang penulis munculkan dalam kesimpulan kepada guru kelas B di RA AR-Raudhah Sibolga Sumatera Utara, maka ada beberapa saran yang ingin penulis tekankan disini. Qureean menjadi bagian yang tidak terpisahkan dari perjalanan panjang di RA ARRaudhah Sibolga Sumatera Utara. Dari awal berdiri di tahun 2007, sampai saat ini menjadi salah satu identitas. Oleh karena itu, sekolah harus menjaga keberlangsungan Metode Kisah Qurean karena banyak manfaat dan hal positif dari pembelajaran akhak dalam mendukung perkembangan, potensi, dan kreativitas anak. 
http://jurnaltarbiyah.uinsu.ac.id/index.php/raudhah

e-mail: jurnalraudhah@uinsu.ac.id

p-ISSN: 2338-2163

e-ISSN: 2716-2435

1. Proses pembelajan dengan mengunakan Metode Kisah Qur an di di RA AR-Raudhah Sibolga Sumatera Utara harus terus dikembangkan dan disempurnakan, salah satunya tentang alokasi waktu. Menurut penulis, alokasi waktu untuk pembelajaran kisah para nabi ini sangat terbatas. Mengingat begitu banyak mamfaat dan pengaruh positif dari belajar tentang akhlak, sudah seyogyanya lembaga sekolah untuk mengambil kebijakan yang trategis dalam rangka mengembangkan potensi dan kreativitas anak melalui metode kisah Qurean untu lebih maksimal. Selain itu, guru tari seyogyanya memberi waktu dan kesempatan yang lebi bagi untuk lebih mengembangkan pemahaman anak dalam melakukan praktik sifat-sifat para nabi sesuai dengan ide kreativitasnya. Karena bagaimanapun, metode kisah Qur"ean ini yang baik adalah dari anak, oleh anak dan untuk anak itu sendiri.

2. Sekolah harus lebih membangun sinergitas dengan orangtua anak, dengan terus berupaya untuk menjalin komunikasi terkait keberlanjutan penanaman nilai dan moral anak, yang sudah ditanamkan dan dikembangkan di sekolah salah satunya melalui berkisah tentang para nabi untuk tetap berjalan dirumah untuk hasil yang lebih optimal. Dalam hal ini, kerja sama dan komunikasi yang efektif antara pihak sekolah dan orang tua menjadi hal yang tidak bisa ditawarkan lagi.

\section{DAFTAR PUSTAKA}

Affani Syukron, "Rekonstruksi Kisah Nabi Musa Dalam Al-Quran: Studi Perbandingan Dengan Perjanjian Lama,” Jurnal Al-Ihkam 12, no. 1 (2017): hlm. 195., https://doi.org/10.19105/alihkam.v12i1

Ahmad Susanto.. Perkembangan Anak Usia Dini Pengantar dalam Berbagai Aspeknya. Jakarta: prenandamedia group, 2011

al-Hamid Al-Kurdi Rajih Abd, Nazhariyat Al-Ma'rifah Bain Al-Qur'an Wa AlFalsafah (Riyad: Maktabah al-Muayadah, 1992),

Al-Qathathan Syaikh Manna, Pengantar Study Ilmu Al-Qur'an (Jakarta: Pustaka Al- Kautsar,2006), Antonius Atosokhi Gea, Antonina Panca Yuni Wulandari, and Yohanes Babari, Relasi Dengan Sesama Character Building II, 3rd ed. (Jakarta: PT Elex Media Komputindo, 2005).

Arikunto Suharsimi, Prosedur Penelitian: Suatu Pendekatan Praktek (Jakarta: Rineka Cipta, 2002),

Aziz Suismanto dan Hafidh, Qashashul Qur'an Bekal Utama Juru Kisah (Yogyakarta: Akademi Berkisah, 2018

Bagir Haidar, Memulihkan Sekolah Memulihkan Manusia: Meluruskan Kembali Falsafah Pendidikan Kita (Bandung: Mizan, 2019)

Implimentasi Pendekatan Metode Kisah Qur'an Nilai Religiusdan Moral Di Ra Ar-Raudhah Anak Usia Dini Kota Sibolga Sumatera Utara 
http://jurnaltarbiyah.uinsu.ac.id/index.php/raudhah

e-mail: jurnalraudhah@uinsu.ac.id

p-ISSN: 2338-2163

e-ISSN: 2716-2435

Dalimunthe Sehat Sultoni, "Metode Kisah Dalam Perspektif Al-Qurean,” Jurnal Tarbiyah 23, no. 2 (2016):

Dister Nico Syukur, Psikologi Agama (yogyakarta: KANISIUS, 1989).,

Eva Eriani, "Story Telling Using Madihin : Learning Methods for Early Childhood Listening Skills," Jurnal Obsesi : Jurnal Pendidikan Anak Usia Dini 3, no. 2 (2019): https://doi.org/10.31004/obsesi.v3i2.172.

H. Jalaluddin, Psikologi Agama (Jakarta: PT Raja Grafindo Persada 2016),,

Harun Rasyid Dkk, Assasemen Perkembangan Anak Usia Dini (yogyakarta: Gama Media, 2012)., HidayaOtib Satibi t, Metode Pengembangan Moral Dan Nilai- Nilai Agama, pertama (Tanggerang Selatan: Universitas Terbuka, 2014

Jauhari Heri, Cara Memahami Nilai Religius Dalam Karya Sastra Dengan Pendekatan Reader's Response (Bandung: CV ARfino Raya, 2010).

Khadijah, Perkembangan Kognitif Anak Usia Dini (Medan: Perdana Publishing, 2017

Khoironi Mulianah,. Pendidikan Moral Pada Anak Usia Dini. Jurnal Golden Age Universitas Hamzanwadi Vol. 01 No. 1, Juni 2017.

Kolberg Lawrence.. Tahap-tahap Perkembangan Moral. Yogyakarta: KANISIUS; 1995

Laura A. King.. Psikologi Umum Sebuah Pandangan Apresiatif The Science Of Psychology-An Apprective View. Edisi 3 buku 1. Jakarta: salemba humanika, 2016

Masdalipah Dkk, "Implementasi Model Tematik Dalam Pembelajaran Agama Islam Pada Pendidikan Anak Usia Dini di Raudhatul Athfal Al-Jihad," Ta'dibuna 6, no. 1 (2017):

Masganti Sit, "Mengembangkan Sikap Cinta Allah Dan Rasul Melalui Metode Kisah

Ramdani Febriant Musyaqori, Achmad Hufad, and Udin Supriadi, "Program Internalisasi Nilai Pendidikan Karakter Pada Anak Usia Dini," Sosietas 7, no.2(2018): https://doi.org/10.17509/sosietas.v7i2.10355

Ridla Muhammad Jawwad, Tiga Aliran Utama Teori Pendidikan Islam (Perspektif

Implimentasi Pendekatan Metode Kisah Qur'an Nilai Religiusdan Moral Di Ra Ar-Raudhah Anak Usia Dini Kota Sibolga Sumatera Utara 